\title{
EL PATROCINIO ARTÍSTICO DEL REGIDOR ÁLVARO PÉREZ OSORIO EN LA CATEDRAL DE MONDOÑEDO (1615-1641)
}

\section{THE ARTISTIC SPONSORSHIP OF COUNCILLOR ÁLVARO PÉREZ OSORIO IN MONDOÑEDO CATHEDRAL (1615-1641)}

\author{
Javier Gómez Darriba \\ Francisco Javier Novo Sánchez
}

\section{RESUMEN}

El presente trabajo trata la dotación artística de la capilla de la Concepción de la catedral de Mondoñedo, llevada a cabo por un matrimonio perteneciente a la hidalguía local. En él se analizan las obras de arquitectura, pintura, escultura, rejería y platería realizadas por diversos artistas flamencos, alemanes, gallegos y cántabros, aportándose nuevos datos sobre figuras como Martín de Balenzate, Juan de Biorín, Juan de Castro o Crispín de Evelino entre otros.

Palabras clave: Retablo, Escultura, Pintura mural, Galicia, Siglo XVII.

\section{ABSTRACT}

This paper addresses the artistic endowment of the Conception Chapel in Mondoñedo Cathedral, carried out by a married couple belonging to the local nobility. It analyses the works of architecture, painting, sculpture, blacksmithing and silversmithing made by various Flemish, German, Galician and Cantabrian artists, providing new information on figures such as Martín de Balenzate, Juan de Biorín, Juan de Castro and Crispín de Evelino, among others.

Keywords: Altarpiece, Sculpture, Mural painting, Galicia, 17th century. 
En 1603 concluyeron las obras de la cabecera de la catedral de Mondoñedo, cuyo impulsor circunstancial fue Nicolás Beche, un rico mercader que solo pretendía erigir una capilla en el templo. El testero, diseñado por el trasmerano Pedro de Morlote, contaba con cuatro capillas de planta cuadrangular abiertas a la girola por un arco de medio punto aupado en pilastras toscanas, cuyo interior se cubría con una bóveda de crucería. Estos recintos habían sido concebidos para que las familias más pudientes de la urbe instaurasen allí sus fundaciones pías, las cuales supondrían un jugoso beneficio a una Iglesia tan escasa de rentas como la mindoniense. La ubicación de dichos espacios era privilegiada, pues se hallaban detrás de la capilla mayor y ante el altar de las reliquias (Gómez Darriba, 2018: 239-259; 2020: 42-46, 157-178). En 1614 se depositaron aquí las de san Rosendo, patrono de la diócesis (Lence-Santar y Guitián, 1910a: 141152; Cal, 2003: 429-432). Su llegada a esta capital del Reino de Galicia resultó un acontecimiento y prestigió al deambulatorio como lugar de entierro. Pasados cuatro meses de la efeméride, Álvaro Pérez Osorio Rengifo y María Marquesa de Miranda solicitaron inhumarse en una de las capillas. Estos hidalgos constituían el matrimonio más célebre de Mondoñedo. Él era regidor del Concejo이 ${ }^{1}$ regentaba una compañía ballenera en el puerto de Rego de Foz (Lence-Santar y Guitián, 1950: 100-102); y ostentaba la mayordomía del santuario de Los Remedios, una ermita de patronazgo episcopal². Carecían de hijos y sobresalían por emprender múltiples obras caritativas, algunas de las cuales dejaron dispuestas a su muerte ${ }^{3}$. En los siguientes párrafos analizaremos el patrocinio artístico que llevaron a cabo en la catedral mindoniense.

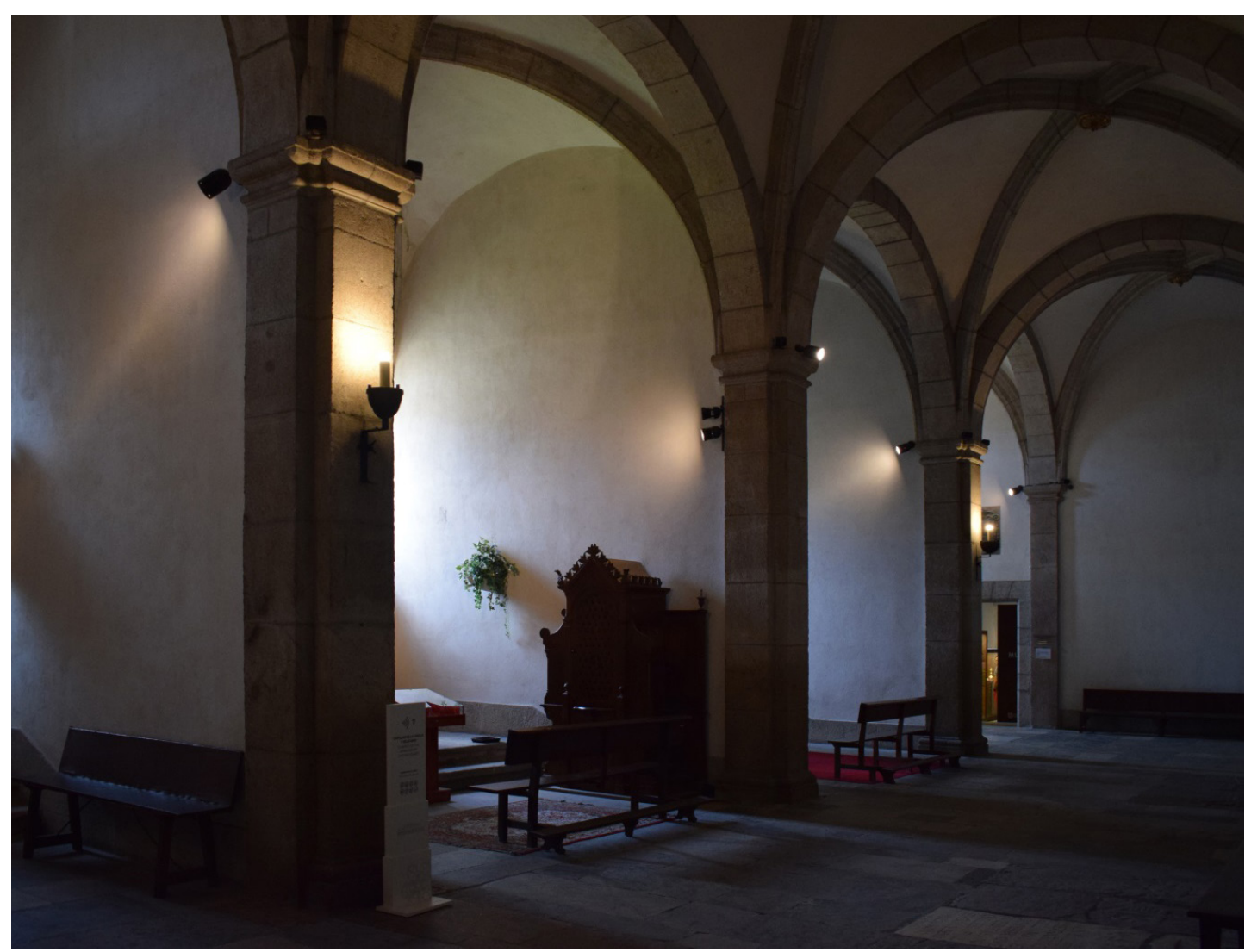

Figura 1. Capillas de la girola de la Catedral de Mondoñedo. Pedro de morlote (1597-1603). Fotografía del autor.

En febrero de 1611 decidieron testar por hallarse Álvaro enfermo. Pidieron dotar una de las dos capillas de la girola que quedaban libres -sin concretar cuál-, dedicarla a la Virgen y celebrar en ella a perpetuidad una misa rezada diaria y dos cantadas por las fiestas de la Inmaculada y de san Antonio de Padua. También solicitaron enterrarse ante el altar mayor

\footnotetext{
1 Tomó posesión el 28 de septiembre de 1601, Arquivo Municipal de Mondoñedo (en adelante AMM), Carp. 923, Libro de Actas (1595-1608), ff. 174r.-174v.

2 Archivo Histórico Nacional (en adelante AHN), Clero Secular Regular, leg. 6373.

3 Álvaro falleció en Mondoñedo el 24 de noviembre de 1631. Su esposa el 14 de agosto de 1639 (Lence-Santar y Guitián, 1911: 38-41, 89-90).
} 
de la catedral junto a las sepulturas de sus progenitores para que, cuando fuese posible, sus herederos trasladasen sus restos y los de sus antecesores a la capilla ${ }^{4}$. El 27 de febrero de 1615 el obispo Alfonso Mesía de Tovar anunció al Cabildo el deseo del matrimonio de adquirir la que se ubicaba junto a la parroquial de Santiago -hoy del Eccehomo- ${ }^{5}$. El 29 de abril rubricaron la dotación en presencia del prelado. Acordaron que el recinto, dedicado hasta la fecha a san Antonio, se convirtiese en su lugar de entierro. Allí podrían patrocinar un ajuar litúrgico a su gusto y encastrar sus escudos de armas a cambio de 4.000 reales. Los canónigos, por su parte, oficiarían las misas dispuestas en $1611^{6}$.

Los patronos no se demoraron en costear el mobiliario y el 21 de julio de 1615 ajustaron la construcción de un retablo con los escultores Juan de Biorín y Martín de Balenzate. El contrato indica que los artistas habrían de configurar un mueble de madera de nogal formado por tres cuerpos asentados en un banco. Se articularía con columnas de fuste estriado y capitel corintio que flanquearían siete nichos de bóveda avenerada, cinco de los cuales albergarían imágenes de la Inmaculada, san Antonio de Padua, san Francisco de Asís, santa Catalina de Alejandría y el Crucificado. El banco contendría escenas en medio relieve de la Resurrección, la Santa Cena y la Natividad, así como figuras de los evangelistas. En cada columna habría "santos y santas de medio talle" sin especificar advocación; y en el remate el Padre Eterno en relieve con "cartelas a los lados y sus pirámides". En el par de cajas restantes se dispondrían dos imágenes preexistentes de santa Ana y san Roque. Este programa iconográfico contaba con la aprobación de tres canónigos que lo verificarían una vez concluida la obra. Los artífices habrían de esculpir asimismo un florón lignario para ornamentar la clave de la bóveda, cobrando por su trabajo 1.100 reales?

Estos entalladores resultan prácticamente desconocidos por la historiografía. Biorín era flamenco porque así lo indica un contrato que le hizo el Cabildo de Mondoñedo en 1592 para que ejecutase los remates de las rejas lignarias de los cinco altares que rodeaban el coro catedralicio ${ }^{8}$. Este documento y el anteriormente citado lo reseñan como maestro de arquitectura, término que alude a su faceta de tracista y ensamblador. En 1611 estaba avecinado en la feligresía de Santa Eulalia de Merille (Ourol, Lugo). Entonces se le encomendó reformar el retablo mayor de la iglesia conventual de San Francisco de Viveiro (Pérez Costanti, 1930: 58). La última noticia que lo acredita vivo data de septiembre de 1625. Continuaba residiendo en la antedicha parroquia y estaba desposado con María Rodríguez ${ }^{9}$. Una escritura por razón de un pleito con fecha del 12 de marzo de 1644 indica que una de las partes litigantes le había comprado a "Juan de Biorín escultor" una casa con huerta en Mondoñedo. Pero no especifica el momento, la situación concreta de la propiedad o que el artista viviese ${ }^{10}$. Existe un último documento de 1648 que alude a Biorín y a una vivienda en la antigua Rúa de Batitales, pero tampoco revela que estuviese vivo ${ }^{11}$. De Martín de Balenzate ignoramos su procedencia. No sería de extrañar que, al igual que Biorín, fuese extranjero y su nombre y apellido resultasen una adaptación a la tierra de acogida, en este caso Mondoñedo, donde fue vecino durante décadas. Entre los últimos años del siglo XVI y 1603 realizó el retablo mayor y los colaterales de la citada ermita de Nuestra Señora de Los Remedios, cobrando por su trabajo un total de 122 ducados. Cabe la posibilidad de que entonces ejecutase una talla de la titular del templo ${ }^{12}$. En junio de 1603 actuó como testigo del aparejador trasmerano Francisco de Castañeda, quien había sido contratado para llevar a cabo la cubrición de la flamante cabecera de la

\footnotetext{
4 Archivo Histórico Provincial de Lugo (en adelante AHPL), Protocolos Notariales de Mondoñedo, Domingo Rodríguez Bermúdez, leg. 7192-1, ff. 7r.-15v.

5 Archivo de la Catedral de Mondoñedo (en adelante ACM), Actas Capitulares, vol. 10, ff. 53v.-54r., 95 r.

6 AHPL, Protocolos Notariales de Mondoñedo, Juan Abad, leg. 7211-2, ff. 52r.-57v., 269r.-270r.; ACM, arm. 3, est. 1, leg. 4, ff. 42r.-46v.; (Cal Pardo, 1992a: 402-403).

7 AHPL, Protocolos Notariales de Mondoñedo, Domingo Rodríguez Bermúdez, leg. 7193-1, ff. 144r.-145v.

8 AHPL, Protocolos Notariales de Mondoñedo, Domingo Rodríguez Bermúdez, leg. 7009-1, ff. 13r.-15r.

9 En aquella fecha pagaron 184 reales y 11 maravedíes que le debían al campanero Bartolomé Calaza, AHPL, Protocolos Notariales de Mondoñedo, Pedro Fernández Villapol, leg. 7350, ff. 120r.-122v. (1. a foliación).

10 AHPL, Protocolos Notariales de Mondoñedo, Domingo López de Miranda, leg. 8172-1, f. 42r.

11 AHPL, Protocolos Notariales de Mondoñedo, Juan de Legaspe Barcal, leg. 7316-3, ff. 129r.-129v.

12 Balenzate apenas sabía firmar. Ello no solo lo denota su caligrafía sino que él mismo lo reconoció, AHN, Clero Secular Regular, leg. 6373, ff. 91v.-93r.
} 


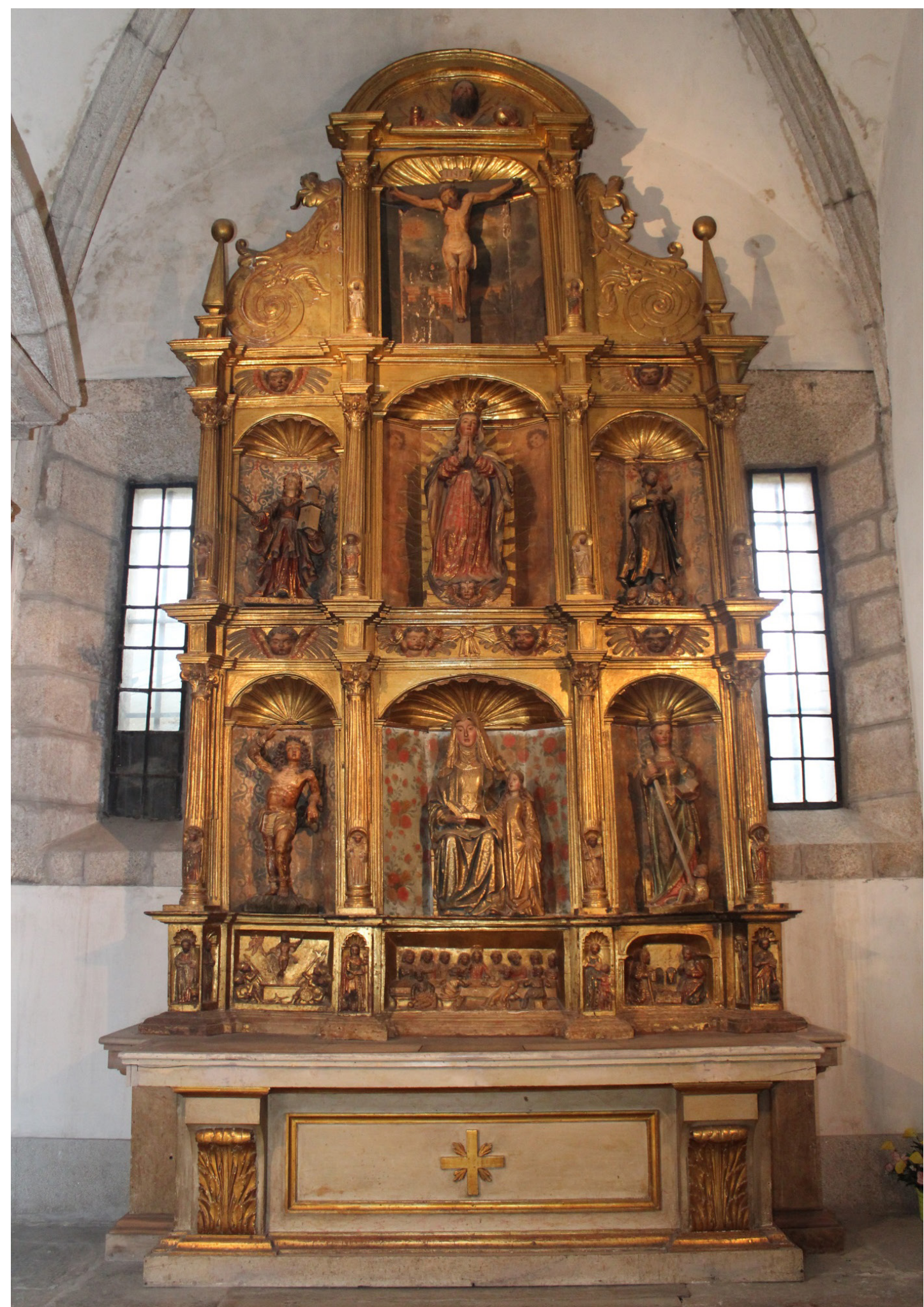

Figura 2. Retablo de la capilla de Nuestra Señora de la Concepción. Catedral de Mondoñedo. Juan de Biorín y Martín de Balenzate (1615). Fotografía del autor.

catedral diseñada por Pedro de Morlote ${ }^{13}$. El 6 de mayo del año siguiente el abad de Santa María de Villanueva de Oscos (Asturias), fray Andrés de Verdenoso, le encargó por 22 ducados la materialización de una mesa de nogal idéntica a la que había realizado para el monasterio benedictino de San Salvador de Vilanova de Lourenzá, a tan solo $8 \mathrm{~km}$ de Mondoñedo. El clérigo le ofrecería una cabalgadura y un mozo para que pudiera trasladarla desde la capital 
episcopal hasta el cenobio cisterciense con la finalidad de ensamblarla in situ ${ }^{14}$. En 1619 estaba casado con María Pérez ${ }^{15}$. Un documento del 22 de febrero de 1621 indica que vivía en la rúa mindoniense dos Ferreiros ${ }^{16}$. Pero una escritura del 28 de agosto de 1623 revela que había muerto, sin especificar la fecha del óbito ${ }^{17}$. Lo que se conoce de su trayectoria artística y el hecho de que apenas supiese firmar lo descartan como tracista del retablo objeto de estudio.

Álvaro Pérez Osorio quedó descontento con el trabajo de Biorín y Balenzate. Lamentó que no habían dejado el mueble "tan perfecto y acabado como era menester", así que el 5 de marzo de 1626 acordó con el escultor local Juan de Castro retocar los "rostros, cabelleras y ropaje" de todas las figuras, así como "pulir y perfeccionar las columnas, frisos, trabes, arquitrabes, pedestales y todo lo demás que fuere concerniente al dicho retablo". También le mandó tallar una imagen de Nuestra Señora de la Concepción y transformar la vieja en un san Pedro con sus llaves. Por su labor le ofreció 375 reales $^{18}$. Los trabajos debieron circunscribirse a dicho mes, pues el día 29 el obispo fray Rafael Díaz de Cabrera ordenó restituir en la capilla las tallas de santa Ana y san Roque extraídas previamente por el fabriquero ${ }^{19}$. Existen más motivos para creer que la intervención de Castro no pudo ser muy notoria, como el bajo precio por el que fue contratado o que el mueble conserve todos los elementos que reseña la escritura de 1615. No obstante, es posible que interviniese en el rostro de la santa Catalina a juzgar por las semejanzas que presenta con la Virgen de la Concepción ${ }^{20}$.

El retablo cuenta con una planta estática propia de una obra manierista. Se divide en banco, dos cuerpos separados por entablamentos, tres calles y ático. Los nichos presentan respaldo poligonal, siendo los del eje central de mayor capacidad. Las hornacinas, aletones, pináculos y columnas con el tercio inferior tallado responden a las cláusulas escrituradas en 1615. Se asemeja a otros retablos ensamblados en el primer quindenio del siglo XVII en la zona occidental del Principado de Asturias, cercana a Mondoñedo, y debidos a entalladores como Juan Menéndez del Valle, Juan de Medina Cerón o Antonio Ruiz ${ }^{21}$. Existe en ellos una semejante distribución de cuerpos y calles, una articulación análoga, idéntica tipología de Padre Eterno en el remate y unos mismos querubines en los frisos. Estas particularidades entroncan con el estilo de Juan de Castro, quien a los pocos meses de haber intervenido en la capilla de Álvaro Pérez ejecutó el retablo mayor de la colegiata asturiana de San Salvador de Grandas de Salime (Ramallo Asensio, 1985: 132-135; Fernández Fernández, 2017: 239-262), obra en la que reiteró algunas de las características antedichas. El conjunto de estas concomitancias se justifica porque los escultores citados pertenecían a una misma generación ${ }^{22}$. De hecho debían de trabajar juntos puntualmente, pues en 1619 Castro fue contratado para ensamblar un retablo diseñado por él en la citada iglesia monasterial de Vilanova de Lourenzá y Balenzate actuó de fiador ${ }^{23}$. El mueble no se conserva, pero el templo cuenta en la nave de la Epístola

14 Entre los testigos presentes en esta escritura compareció el carpintero Bartolomé Fernández, vecino de Mondoñedo, AHPL, Protocolos Notariales de Ribadeo, Jácome Rodríguez de Labrada, leg. 1743-8, ff. 23r.-23v.

15 AHPL, Protocolos Notariales de Mondoñedo, Domingo Rodríguez Bermúdez, leg. 8374-3, ff. 46r., 47v., 50v.

16 AHPL, Protocolos Notariales de Mondoñedo, Juan Abad, leg. 7212-1, f. 25r.

17 Se trata de la obligación de pago de una pequeña deuda. En ella también se alude a su viuda María Pérez, AHPL, Protocolos Notariales de Mondoñedo, Domingo Rodríguez Bermúdez, leg. 8375-2, f. 186r.

18 AHPL, Protocolos Notariales de Mondoñedo, Domingo Rodríguez Bermúdez, leg. 8376-2, ff. 31r.-32r. Ni Castro era pintor ni el patrono lo contrató para que policromase el mueble, como asegura Pérez Costanti (1930: 100). Coetáneamente le encargó varias obras en la ermita de Los Remedios, AHN, Clero Secular Regular, leg. 6373, ff. 74r., 112v.

19 ACM, Actas Capitulares, vol. 10, ff. 574v.-575r. y arm. 3, n. 41, ff. 107r.-107v.; (Cal Pardo, 2003: 451).

20 En la iglesia de Santiago de Pontedeume (Pontedeume, A Coruña) se conserva una imagen de santa Catalina prácticamente idéntica a la mindoniense. Es posible que fuese ejecutada en el último tercio del siglo XVI (Castro Álvarez y Vázquez Arias, 2003: 101-102).

21 Sobre estos véase Fernández Fernández (2018: 82-83, 110-111, 137-138, 151, 153).

22 Ignoramos cuándo nacieron, pero como hemos dicho, Balenzate falleció entre 1621-1623. La última noticia que acredita vivo a Biorín data de 1625 y Juan de Castro finó en 1633 (Fernández Fernández, 2017: 242).

23 El encargo se escrituró en Mondoñedo el 31 de julio. Como parte contratante actuó Juan Gutiérrez de Torices, arcediano de Montenegro en la catedral mindoniense. La traza de la obra no se conserva. De ella apenas se reseña que contaría con "labores y ángeles y figuras", así como con cuatro flamantes esculturas de bulto redondo, de las que no se indica su advocación, aunque se supone que dos serían de santo Domingo y san Antonio. El mueble se haría de madera de nogal y debería estar terminado para el día de Navidad. Castro cobraría 50 ducados por su trabajo. A la hora de rubricar, como en tantas otras ocasiones, acompañó con orgullo su nombre de la palabra "hescultor", y lo hizo con muy buena caligrafía, AHPL, Protocolos Notariales de Mondoñedo, Domingo Rodríguez Bermúdez, leg. 8374-3, ff. 213r.-214v. La capellanía que motivó la construcción del retablo estaba dedicada a los santos referidos. La había fundado el 3 de marzo de 1618 el bachiller Domingo de Río y Moscoso con la aprobación del obispo Pedro Fernández Zorrilla. El citado arcediano era el capellán. El mueble se hallaba dentro de la reja del antiguo templo monasterial, en el trascoro y frente al retablo de Santa Ana (Lence-Santar y Guitián, 1910b: 6). 


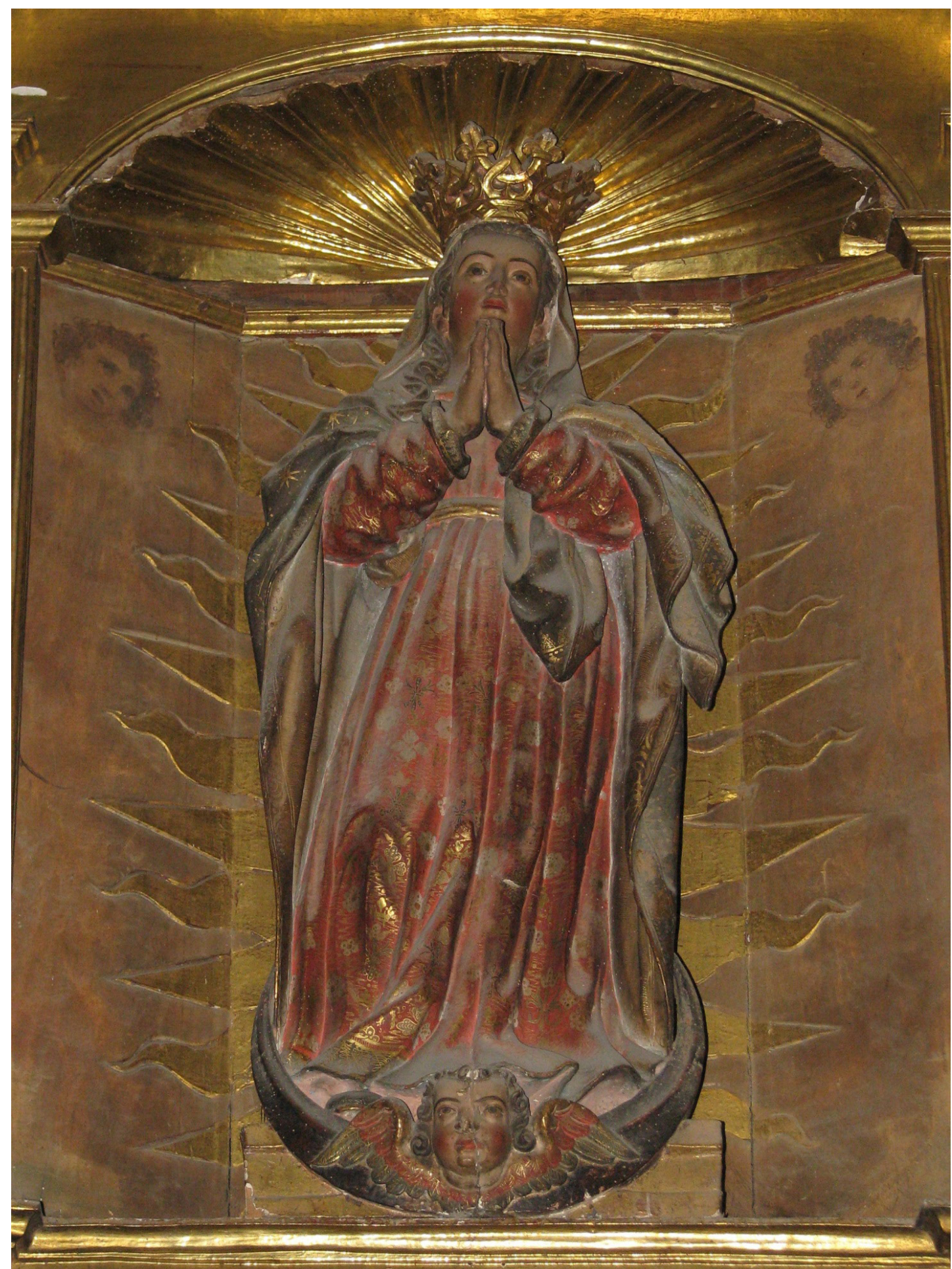

Figura 3. Nuestra Señora de la Concepción. Catedral de Mondoñedo. Juan de Castro (1626). Fotografía del autor.

con un retablo de autoría desconocida dedicado en origen a san Sebastián que presenta varios elementos arquitectónicos y escultóricos ajenos al mueble primitivo. Se realizó en 1582 porque así lo indica la columna del extremo derecho del primer cuerpo. Sus soportes muestran en el tercio inferior un exorno afín a los de Grandas: tarjas ovaladas, putti, cintas y vegetales. También reproducen el capitel corintio y solo el fuste entorchado se sustituye por otro de acanaladuras verticales. La composición de los entablamentos es casi calcada en lo que a movimiento, molduras, denticulado o presencia de serafines en el friso se refiere. En ambos existen elementos que se aprecian en el retablo de la capilla de Álvaro Pérez Osorio, como el Dios Padre de la cima, los aletones en espiral guarnecidos con decoración vegetal o 


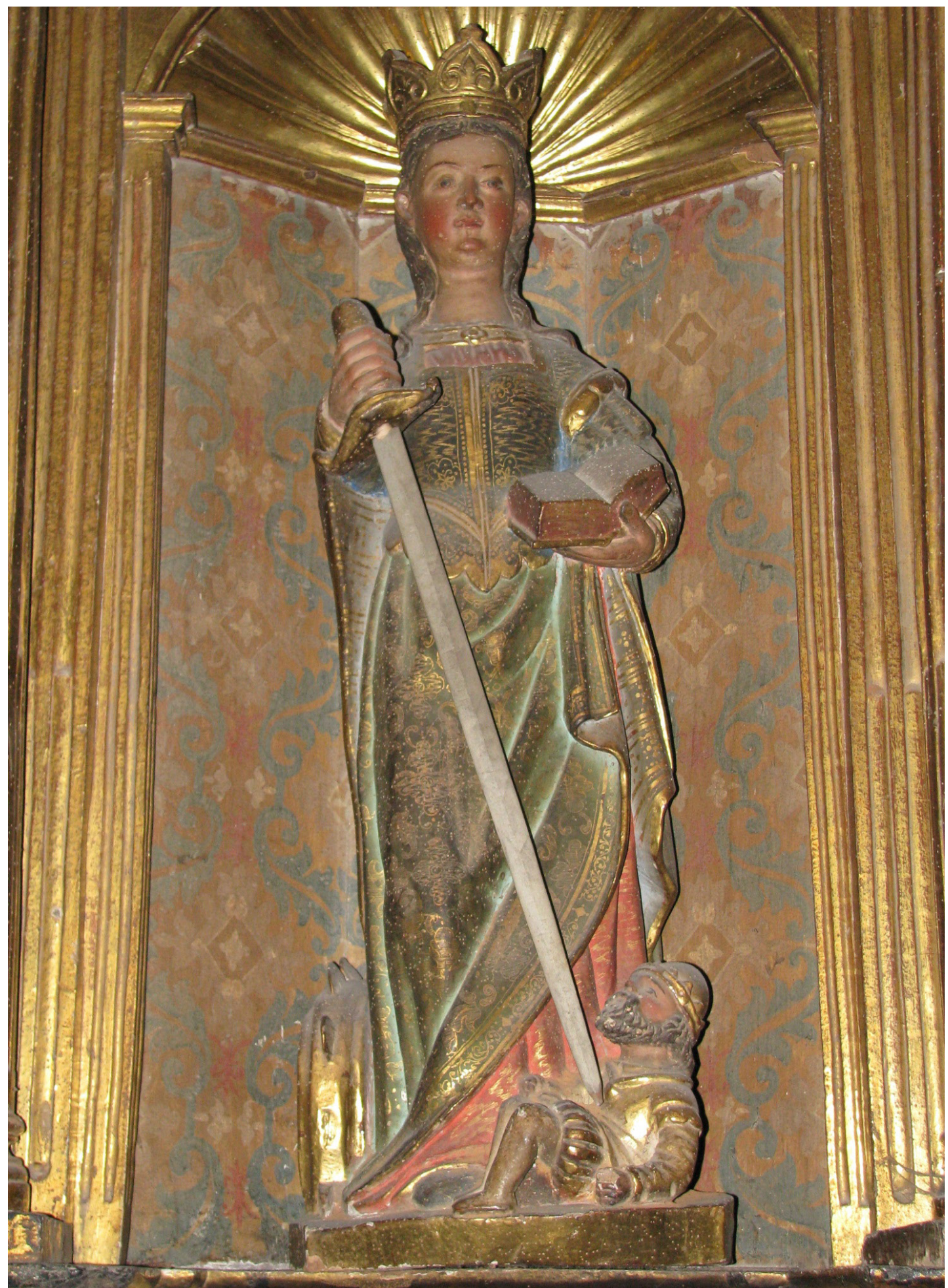

Figura 4. Santa Catalina de Alejandría. Catedral de Mondoñedo. Juan de Biorín y martín de Balenzate (1615). Fotografía del autor.

aquellos otros culminados por cabezas monstruosas que exhiben sus largas lenguas ${ }^{24}$. Todas estas características indican lo retardatario que resulta el mueble catedralicio desde el punto de vista estilístico.

En la actualidad cuenta con siete imágenes de bulto aunque no todas pertenecen al programa original. A este corresponden el Crucificado y la santa Catalina, salidos de la

24 Dichas testas también se aprecian en los aletones de otros retablos de la Mariña Lucense, caso del mayor de la capilla de san Pedro da Torre, en la periferia de Mondoñedo, o del que preside la nave de la Epístola de la iglesia parroquial de Santa Eulalia de Budián (O Valadouro) 


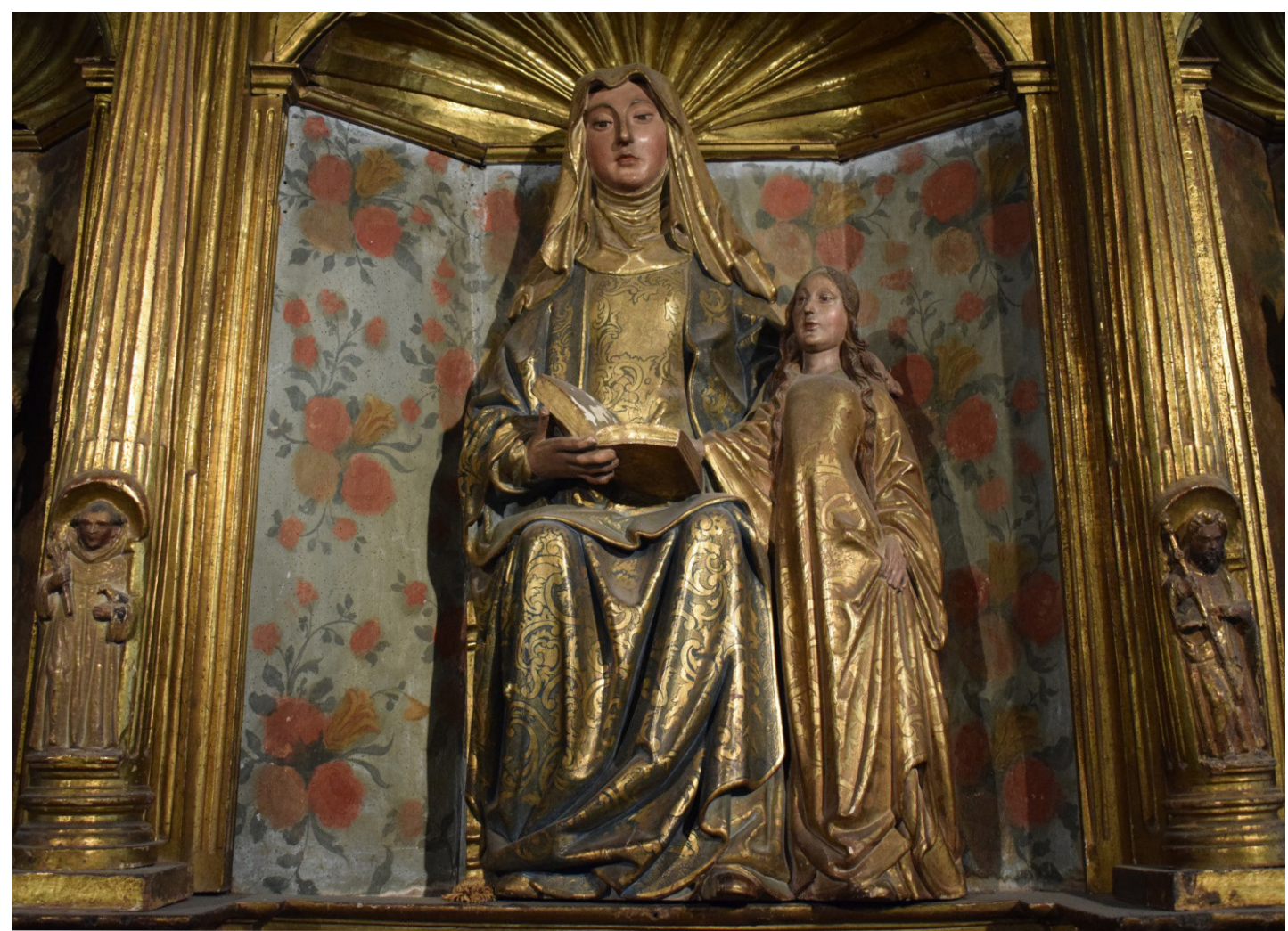

Figura 5. Santa Ana enseñando a leer a la Virgen. Catedral de Mondoñedo (ca.1500). Fotografía del autor.

gubia de Biorín y Balenzate independientemente del retoque que pudieran haber sufrido con Castro. También se debe al mueble primigenio el grupo escultórico de santa Ana enseñando a leer a la Virgen. Este había llegado desde Inglaterra hasta el puerto de Ferrol en 1550 junto a una talla mariana con el Niño. Cinco años después se trasladó a la catedral (Lence-Santar y Guitián, 1951: 65-70, 80-81). En 1590 el obispo Isidro Caja de la Jara giró una visita y ordenó hacer un retablo dedicado a santa $\mathrm{Ana}^{25}$. No consta que se materializase, pero dos años antes de que Biorín y Balenzate hiciesen el mueble objeto de estudio su altar se hallaba bajo los viejos órganos ${ }^{26}$. Sea como fuere, se ignora su autoría y fecha de ejecución. Franco Mata la vincula a talleres ingleses (1998: 932) y Sánchez Ameijeiras al arte flamenco de hacia 1500 (1999: 382-386, 404-406). También se desconoce el paradero del resto de imágenes contratadas en 1615, inclusive el san Pedro requerido a Castro en $1626^{27}$. En cualquier caso, el santoral representa el devocionario particular del matrimonio benefactor. San Antonio era titular de la capilla antes de la dotación, amén de uno de los taumaturgos más socorridos. A san Francisco le rendían gran veneración, pues habían contribuido económicamente a la fundación de un convento seráfico en Mondoñedo y pidieron ser amortajados con su hábito ${ }^{28}$. San Roque, por su parte, era uno de los santos más invocados contra la peste en la Galicia moderna. En Mondoñedo contaba además con una capilla particular. Actualmente el sitio de estas figuras lo ocupan otras de autoría ignota: san Sebastián, san José y santa Bárbara. En la catedral existían tres altares dedicados a estos santos ${ }^{29}$. Quizá su paulatina desaparición condujo a que las imágenes de los titulares se reubicasen en la capilla ${ }^{30}$. La primera y la tercera cabe datarlas hacia 1620-1670, mientras que el san José hacia 1740-1770.

25 ACM, Miscelánea, arm. 4, est. 1, leg. 2, n. 6, s.f.

26 ACM, arm. 3, n. 41 , f. 61v. y n..$^{\circ}$ 2, f. 49r.

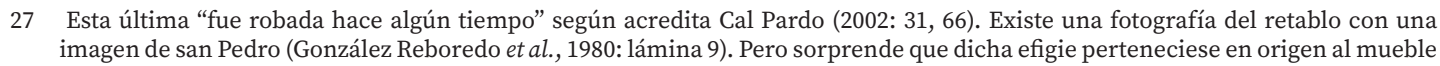
dado su corto tamaño.

28 AHPL, Protocolos Notariales de Mondoñedo, Domingo Rodríguez Bermúdez, leg. 7192-4, ff. 176r.-176v., Francisco Díaz Durán, leg. 7274-4, f. 214r. y del mismo escribano leg. 7277-4, f. 114v.

29 El de Santa Bárbara se hallaba en el claustro.

30 El retablo de San Sebastián se vendió en la década de 1740, ACM, Fábrica, vol. 28-2, f. 26 r. 
El programa original también incluía relieves tallados en la predela y en el tercio inferior de las columnas. En los entrepaños del banco se disponen tres episodios de la Vita Christi: Natividad, Última Cena y Resurrección. Los Evangelios sinópticos y el libro de las Revelaciones de santa Brígida resultan las principales fuentes textuales en las que, en última instancia, se inspiran tales historias. Del último volumen surge la figura de san José iluminando el establo con un candil, al tiempo que se postra junto con la Virgen en actitud orante frente al Niño, acostado en el pesebre. Las dos composiciones restantes se basan en sendos grabados de Cornelis Cort y Hieronymus Wierix. En los netos se horadan pequeños nichos cóncavos terminados en doseletes avenerados. Los ocupan los evangelistas y los Padres de la Iglesia Latina salvo san Jerónimo. En su lugar figura san Juan Bautista. La condición de ambos como penitentes y el papel del Precursor como mediador en las postrimerías y engarce entre el Antiguo y el Nuevo Testamento hacen que el cuarteto apenas se resienta. En los dos lados restantes aparecen ángeles con instrumentos de la Pasión. La parte inferior de las columnas se horada para acoger las imágenes de un variado santoral: en el primer cuerpo figuran (de izquierda a derecha) santa Apolonia, san Nicolás de Tolentino, Santiago el Mayor y santa Lucía; en el segundo san Sebastián, santa Margarita, un santo con atuendo blanco y María Magdalena; en el ático un personaje idéntico al anterior y una mártir cuyos únicos atributos (palma y libro abierto) dificultan su identificación. Los santos ataviados de blanco que sujetan una vasija y una redoma respectivamente podrían tratarse de Cosme y Damián, aun cuando aparezcan a diferente altura ${ }^{31}$. Su presencia redundaría en el importante papel que juegan en el mueble las devociones invocadas contra la peste y otras dolencias. El plan figurativo fue planteado desde la óptica postridentina, cobrando auge la vida del Mesías, los autores de los Evangelios, el culto a los santos y la presencia de los doctores como difusores de la doctrina católica, sirviendo las imágenes de paradigma a los patronos y fieles que acudían al recinto. En el retablo subyace un mensaje iconológico relacionado con la Redención, que se proyecta en última instancia en el sepulcro.

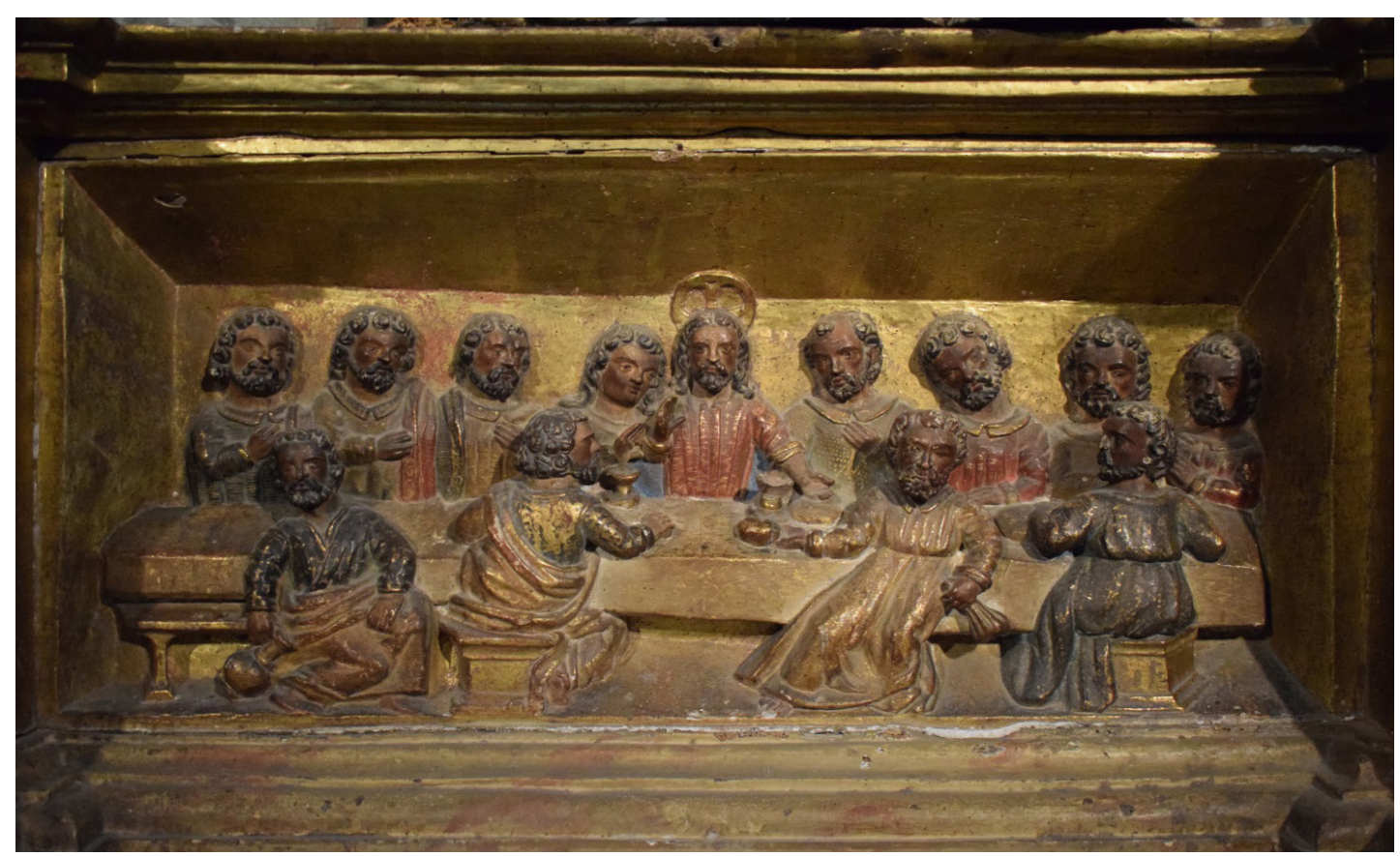

Figura 6. Santa Cena. Catedral de Mondoñedo. Juan de Biorín y Martín de Balenzate (1615). Fotografía del autor.

En un periodo intermedio entre la ejecución del mueble y la ultimación de su imaginería Álvaro Pérez financió la reja. La encargó el 19 de julio de 1622 a los cerrajeros Francisco García y Antonio Rodríguez. El primero era vecino de A Coruña y el segundo de la feligresía de San Pedro Fiz de Baltar (A Pastoriza, Lugo). Tendrían que comenzarla el 1 de noviembre y no

31 En la labor de identificación del santoral hemos recibido la ayuda del catedrático en Historia del Arte D. José Manuel García Iglesias, quien prepara un trabajo sobre la iconografía jacobea en la catedral de Mondoñedo. Aprovechamos para agradecer su colaboración. 


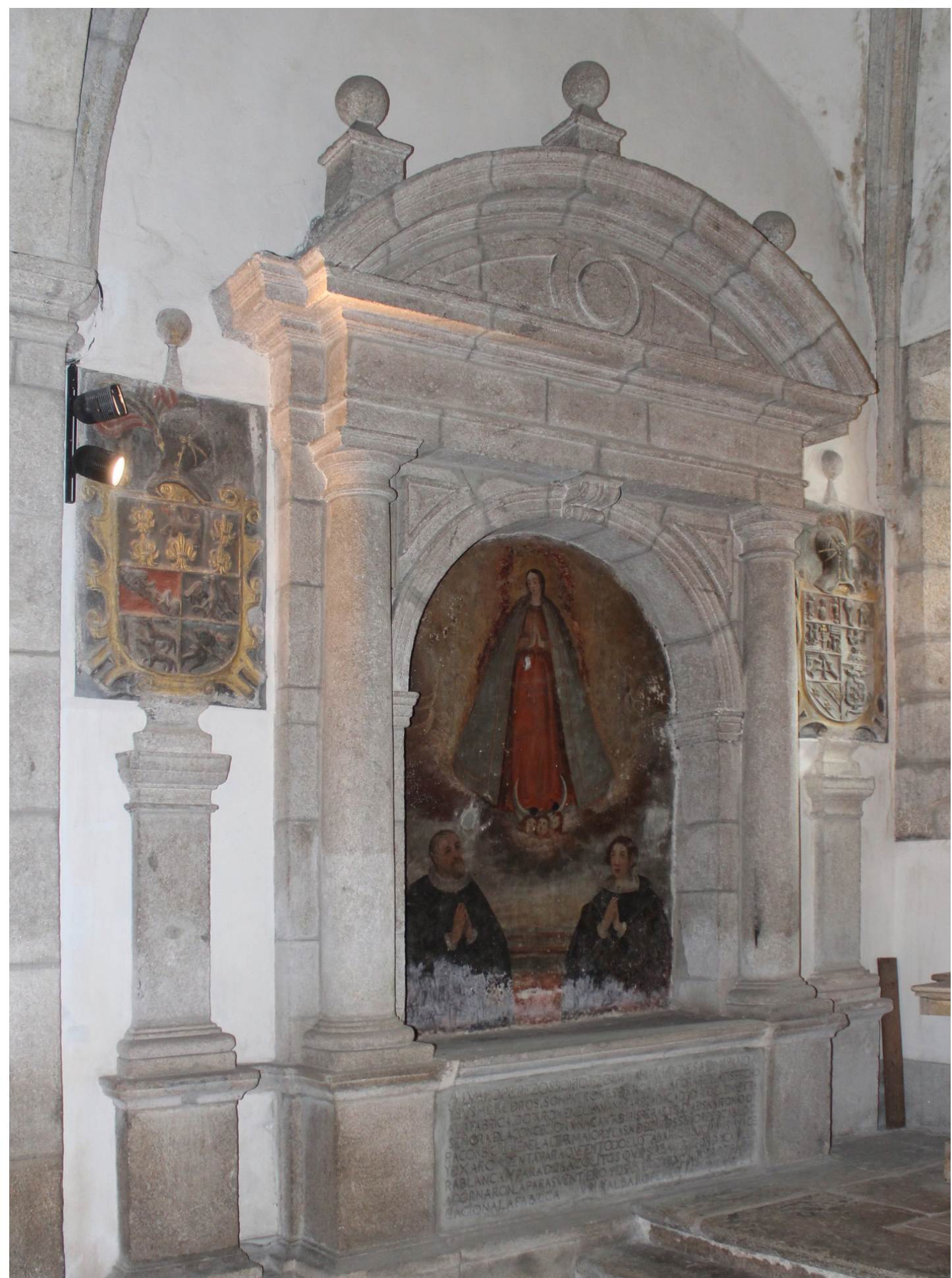

Figura 7. Sepulcro de Álvaro Pérez Osorio y María Marquesa de Miranda. Catedral de Mondoñedo. Diego Ibáñez Pacheco (1635). Fotografía del autor.

desempeñar ningún otro trabajo hasta acabarla. El comitente les proporcionaría el hierro y el carbón necesarios, así como una pipa de vino de la zona, seis fanegas de trigo, una vaca, casa donde hospedarse y 150 ducados. La reja reiteraría el tipo de columnas y balaustres de la que cerraba el coro catedralicio, realizada por el vallisoletano Luis de Estrada entre 1553-1556. También contendría ornato vegetal y las armas del patrono ${ }^{32}$. Lamentablemente ninguna se

32 Actuó como fiador el cerrajero mindoniense Pedro Rodríguez Perrote, AHPL, Protocolos Notariales de Mondoñedo, Domingo Rodríguez Bermúdez, leg. 8375-1, ff. 196r.-197v.; (Pérez Costanti, 1930: 230). Sobre la obra de Estrada véase Cal Pardo (1992b: 105$106,796,799-800)$ 
conserva. En 1669 el cerrajero Juan Fernández de Coroas, vecino de Ribadeo (Lugo), acreditó haber recibido 650 ducados por la ejecución de la reja de la capilla de Nuestra Señora de la Soledad (hoy del Cristo de la Buena Muerte), contigua al recinto objeto de estudio. Tendría la misma "forma y proporción" que esta (Lence-Santar y Guitián, 1911: 25), pero ambas desaparecieron en 1809 (Cal Pardo, 2003: 835).

En 1628 Álvaro Pérez volvió a testar. Expresó que sus devociones predilectas se hallaban esculpidas en el retablo y en caso de morir ordenó dorarlo y estofarlo a excepción de sus hornacinas, cuyo interior se pintaría con "colores finas al óleo". También mandó dorar y policromar la reja, aplicar oro en los nervios de la bóveda y en el florón que la coronaba y blanquear el resto de paredes. Dispuso labrar unos escudos para encastrar en los muros junto con un letrero alusivo a la dotación de la capilla y a las obras pías fundadas por él y su mujer. Por último, dictó que se ejecutase una lámpara argéntea por valor de 100 ducados $^{33}$. Muerto en 1631, su viuda hizo testamento el 2 de mayo de 1634. Ordenó que sus restos y los de su difunto marido reposasen en una misma tumba ${ }^{34}$. Para tal fin contrató en agosto del año siguiente al arquitecto trasmerano Diego Ibáñez Pacheco, quien realizó el sepulcro por 200 ducados (Lence-Santar y Guitián, 1911: 27-28). Lo adosó al muro del Evangelio y colocó a sus lados los blasones de los patronos sobre unas pilastrillas aupadas en podios ${ }^{35}$. Concibió la tumba a modo de arcosolio sobre pedestal en cuyo frente cinceló el letrero alusivo a la dotación del recinto ${ }^{36}$. $\mathrm{El}$ arco de medio punto lo sustentó en impostas y timbró su clave con una ménsula acanalada. Flanqueó el arco con un par de columnas toscanas que sustentan un entablamento liso sobre el que monta un frontón curvo coronado con esferas. El arcosolio resulta un calco de la portada de la iglesia vitoriana de San Antonio, diseñada en 1611 por los también trasmeranos Juan y Pedro Vélez de la Huerta (Bustamante García, 1983: 468; Ballesteros Izquierdo, 1990: 114-115, 121-122). En última instancia bebe de la tratadística italiana del siglo XVI, fundamentalmente de Vignola y Serlio, cuyas obras custodiaba Ibáñez Pacheco en su biblioteca ${ }^{37}$.

El 4 de agosto de 1639, diez días antes de que le sobreviniera la muerte, María Marquesa escrituró en su codicilo el deseo de pintar en el sepulcro una imagen de la Inmaculada ante su retrato y el de Álvaro Pérez (Lence-Santar y Guitián, 1911: 27). De esta manera se honraría a la advocación titular de la capilla, devoción muy en boga en el Mondoñedo de la época habida cuenta de que cinco años antes el Cabildo, el obispo y el Concejo habían jurado en la capilla mayor de la catedral reconocer la concepción inmaculada de María para que nadie tomase posesión de su cargo sin asumir dicho voto (Cal Pardo, 1992a: 371377). En 1640 destacados miembros del Cabildo se encargaron de cumplir las cláusulas del matrimonio finado, concernientes a la pintura y dorado de las paredes de la capilla, del sepulcro, reja y retablo. Se pusieron al frente de estas cuestiones el deán, el arcediano de Trasancos y los canónigos magistral y doctoral ${ }^{38}$. Este último, en aras de contratar un pintor, mandó distribuir cédulas en Mondoñedo, Santiago y otras ciudades del Reino de Galicia, así como en "Salamanca y Valladolid y otras partes". De todas las posturas que le llegaron aceptó la del artista local Juan González por ser la más baja (1.500 ducados). Se la adjudicó entre septiembre u octubre con la obligación de que tuviese todo listo para 1642. Aparte de las obras antedichas tendría que pintar la piedra epigráfica del sepulcro en color azul, dorar sus letras y representar en el arcosolio a la Inmaculada con los retratos de los fundadores "de rodillas

33 AHPL, Protocolos Notariales de Mondoñedo, Francisco Díaz Durán, leg. 7274-4, ff. 209r. y ss.; ACM, Miscelánea, arm. 2, est. 4, leg. 4, n. ${ }^{\circ}$ 10, ff. 13v. y ss.; (Lence-Santar y Guitián, 1911: 26).

34 AHPL, Protocolos Notariales de Mondoñedo, Francisco Díaz Durán, leg. 7277-4, ff. 85r.-104v., 112r.-122v.; (Lence-Santar y Guitián, 1911: 27).

35 Sobre los escudos véase Rúa Veloso (2005: 33-34).

36 Reza lo siguiente: "Álvaro Pérez Osorio y Doña María Marquesa de Miranda y sus herederos. Son patrones de esta capilla por haber satisfecho a la fábrica. Dotaron en ella una misa rezada cada día y en el de Nuestra Señora de la Concepción una cantada y vísperas y el día de San Antonio otra con vigilia en el altar mayor y las han de decir los señores de Cabildo y dejaron renta para que en todo el octavario del Corpus haya cera blanca y para dos acólitos que sirvan el coro y capilla. Adornáronla para su entierro y de sus herederos libre de toda obligación a la fábrica. Murió Álvaro Pérez año de 1631".

37 En ella también había libros de Alberti, Arfe o Palladio. Sobre estas cuestiones y el sepulcro vid. (Goy Diz, 1996: 236; Fernández Gasalla, 2008: 324-325, 329).

38 AHPL, Protocolos Notariales de Mondoñedo, Francisco Díaz Durán, leg. 7278-1, f. 131r. y Pedro Fernández Villapol, leg. 7352, 1640, ff. 37r., 71r. 
haciendo oración a la Virgen”. Cuando las hermanas de María Marquesa se enteraron de esta operación, denunciaron que los testamentarios habían sido engañados, pues el remate se había efectuado sin rigor, existiendo postores que podrían bajar su precio en más de 600 ducados. En consecuencia, el 19 de octubre se invalidó la antedicha escritura y se prohibió pagar al pintor, que ya había comprado oro y pigmentos en Valladolid por valor de 4.300 reales $^{39}$. Finalmente, el 7 de noviembre los albaceas que no habían establecido contacto alguno con Juan González, esto es, el deán, el arcediano y el magistral, contrataron a tres pintores avecinados en Santiago para que realizasen todo lo dicho por 900 ducados y lo concluyesen antes del 1 de septiembre de 1641. Los artistas eran José Rodríguez, Francisco Velázquez Vaca y Crispín de Evelino ${ }^{40}$. De todos ellos el de mayor renombre era este último, natural de la ciudad germana de Érfurt pero afincado en Compostela desde 1628 (Pérez Costanti, 1930: 160-163; Goy Diz, 2007: 620-628). Se ha dicho que no pudo haber intervenido en el fresco de la capilla dada su mediocridad (Fernández Castiñeiras y Monterroso Montero, 2006: 158). Lo cierto es que apenas se conservan obras suyas como para emitir este juicio. Además, la gran mayoría de las documentadas atañen al dorado y policromía de retablos e imágenes, y no hay que olvidar que fue contratado junto con sus compañeros para pintar la totalidad de la capilla (paredes, sepulcro, retablo y reja). El mueble conserva en buena medida el oro y estofado originales. Alguno de los respaldos de las cajas pudiera haberse repintado en el siglo XVIII, no así la Jerusalén tras el Crucificado. El Cabildo aprovechó la presencia de estos maestros en la catedral para encomendarles más obras. Así, entre marzo y mayo de 1641 Velázquez Vaca pintó los blasones y el letrero epigráfico del claustro, concluido en el año anterior por Diego Ibáñez Pacheco ${ }^{41}$.

Los artistas cumplieron lo estipulado y efigiaron a los patronos en actitud orante ante la Inmaculada. Las figuras conforman una composición triangular. En la mitad inferior del fresco se entrevé lo que parece un paisaje terrestre con montañas al fondo, aunque poco se puede añadir al respecto dado el estado de conservación del mural. La mitad superior la abarca el halo áureo que envuelve a la Virgen, la cual gravita sobre el matrimonio asentada en un trono de nubes y querubines. Viste túnica roja y manto azul. Su canon, el hecho de aparecer efigiada como una adolescente, la disposición de sus manos, los largos mechones ondulados que se descuelgan de sus hombros o la figuración de la media luna con las puntas vueltas hacia arriba, reiteran fidedignamente el modelo iconográfico acuñado por Gregorio Fernández en el primer tercio del XVII ${ }^{42}$. Hacia ella elevan piadosamente la mirada los fundadores. Puede que sus rostros reproduzcan modelos reales, pero lucen una edad madura que nada tendría que ver con la senil a la que hubieron de fallecer. Álvaro viste capa y esclavina negras, puños vueltos hacia fuera mostrando su forro blanco y lechuguilla de igual color. Su esposa lleva capa y jubón negros. Este se abotona en el torso y presenta el mismo tipo de mangas que su marido, así como una valona blanca. Porta pendientes y quizá alguna otra joya en el pecho, pero el estado de conservación del mural impide acreditarlo. Los patronos componen un retrato devocional en el que el protagonismo se divide por igual entre ellos y el culto al que profesan devoción. Su actitud orante en pro de la salvación de sus almas ejemplifica de manera artística la dotación de misas en el recinto. Es posible que el referente compositivo fuese un lienzo ubicado a pocos metros de la capilla, en el altar de las reliquias. El cuadro, debido a Lucas Caamaño (1615) y expuesto actualmente en la sala capitular, muestra al obispo Alfonso Mesía de Tovar arrodillado de igual modo ante san Rosendo ${ }^{43}$.

\footnotetext{
39 AHPL, Protocolos Notariales de Mondoñedo, Francisco Díaz Durán, leg. 7278-1, ff. 98r.-100v., 131r.-132v.

40 En este contrato Juan González actuó como testigo, AHPL, Protocolos Notariales de Mondoñedo, Pedro Fernández Villapol, leg. 7352, 1640, ff. 37r.-37v., 71r.-72r.; (Pérez Costanti, 1930: 161-162, 267).

41 Por la policromía de los tres escudos y del rótulo cobró 10 ducados (Gómez Darriba, 2020: 190).

42 Como ya apuntó García Iglesias (1989: 47). A nuestro juicio no sigue modelos zurbaranescos, como se ha defendido (Fernández Castiñeiras y Monterroso Montero, 2006: 158).

43 Sobre esta obra véase Monterroso Montero (1998: 413-416).
} 


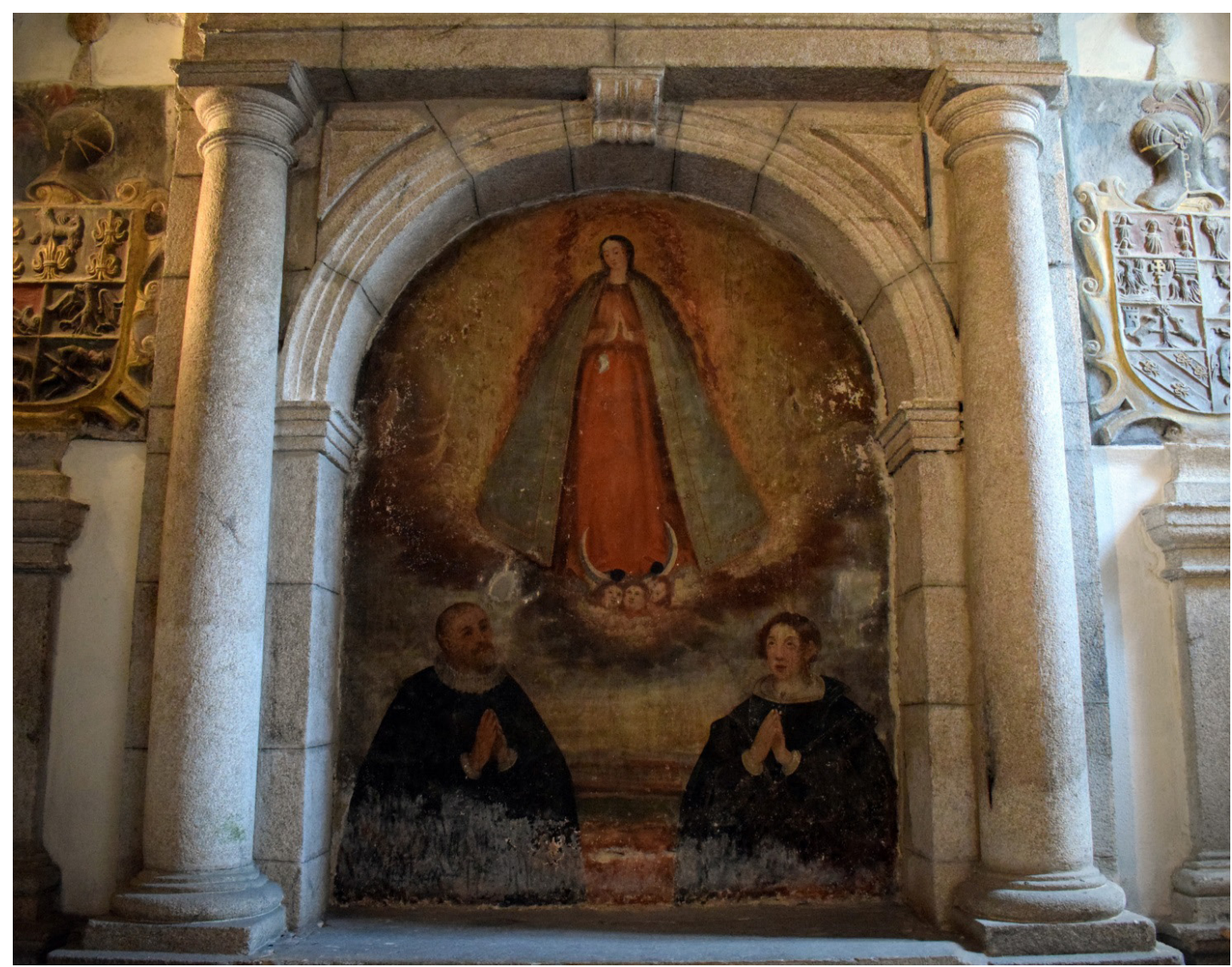

Figura 8. Álvaro Pérez Osorio y María Marquesa de Miranda ante la Inmaculada Concepción. Catedral de Mondoñedo. Crispín de Evelino, Francisco Velázquez Vaca y José Rodríguez (1640-1641). Fotografía del autor.

Finalmente, para completar la dotación artística del recinto, los canónigos que habían contratado a los pintores cumplieron la cláusula testamentaria que concernía a la ejecución de una lámpara argéntea por cuyo peso se habrían de invertir los 200 ducados ordenados por María Marquesa y no los 100 dispuestos por su marido. Los capitulares recurrieron de nuevo a un artista asentado en Compostela, el platero Sebastián Vázquez de Orxas, quien acudió a Mondoñedo el 3 de febrero de 1641 trayendo consigo la "traça" de la alhaja. Recibió 33 marcos y 1 onza de plata para realizarla y le obligaron a entregarla junto con el referido diseño el 18 de octubre de dicho año ${ }^{44}$. Por desgracia no se conserva.

\section{CONCLUSIONES}

En la España del siglo XVII resultó muy común que la nobleza adquiriese capillas catedralicias donde inhumarse y fundar infinidad de misas que garantizasen la salvación de sus almas. Los patronos procuraban que los recintos luciesen con el mayor decoro y ornato posible, pues aparte de exhibir las imágenes de su devoción, guardaban su fama y memoria para la posteridad. A este tipo de dotaciones no fue ajena la catedral de Mondoñedo ni tampoco la oligarquía local, y en este sentido la capilla de la Concepción supone un ejemplo paradigmático. En ella un matrimonio hidalgo promovió el culto inmaculista patrocinando su ajuar e imbricando todas las artes al servicio de la devoción, del prestigio social y de la búsqueda de la gloria eterna.

44 De los 200 ducados que le abonarían, 60 serían por el trabajo, 4 por los desplazamientos y los restantes por el precio del material, AHPL, Protocolos Notariales de Mondoñedo, Francisco Díaz Durán, leg. 7278-2, ff. 137r.-138r.; (Pérez Costanti, 1930: 547). 


\section{FUENTES DOCUMENTALES}

Archivo de la Catedral de Mondoñedo, Actas Capitulares, vol. 10; arm. 3, n. 41 y n. ${ }^{\circ}$ 42; arm. 3, est. 1, leg. 4; Fábrica, vol. 28-2; Miscelánea, arm. 2, est. 4, leg. 4, n. . 10; Miscelánea, arm. 4, est. 1, leg. 2, n. 6; Protocolos Notariales, arm. 2, leg. 2, est. 2-3, n. 26.

Archivo Histórico Nacional, Clero Secular Regular, leg. 6373.

Archivo Histórico Provincial de Lugo, Protocolos Notariales de Mondoñedo, Domingo López de Miranda, leg. 8172-1; Domingo Rodríguez Bermúdez, legs. 7009-1, 7192-1, 7192-4, 7193-1, 8374-3, 8375-1, 8375-2, 8376-2; Francisco Díaz Durán, legs. 7274-4, 7277-4, 7278-1; Juan Abad, legs. 7211-2, 7212-1; Juan de Legaspe Barcal, leg. 7316-3; Pedro Fernández Villapol, legs. 7350, 7352; Protocolos Notariales de Ribadeo, Jácome Rodríguez de Labrada, leg. 1743-8.

Arquivo Municipal de Mondoñedo, Carp. 923, Libro de Actas (1595-1608).

\section{BIBLIOGRAFÍA}

- Ballesteros Izquierdo, T. (1990). Actividad artística en Vitoria durante el primer tercio del siglo XVII: Arquitectura. Vitoria: Diputación Foral de Álava.

- Bustamante García, A. (1983). La arquitectura clasicista del foco vallisoletano (1561-1640). Valladolid: Institución Cultural Simancas.

- Cal Pardo, E. (1992a). El voto-juramento inmaculista en la catedral de Mondoñedo. Estudios Mindonienses, 8, 371-417.

- Cal Pardo, E. (1992b). Mondoñedo-Catedral, Ciudad, Obispado- en el siglo XVI. Catálogo de la documentación del Archivo Catedralicio. Santiago de Compostela: Xunta de Galicia.

- Cal Pardo, E. (2002). La Catedral de Mondoñedo. Historia. Lugo: s. e.

- Cal Pardo, E. (2003). Episcopologio Mindoniense. Santiago de Compostela: CSIC-Xunta de Galicia, Instituto de Estudios Gallegos "Padre Sarmiento"; Mondoñedo-Ferrol: Estudios Mindonienses.

- Castro Álvarez, C. de y Vázquez Arias, J.C. (2003). La iglesia de Santiago de Pontedeume. Historia y patrimonio artístico. A Coruña: Diputación de A Coruña.

- Fernández Castiñeiras, E. y Monterroso Montero, J. M. (2006). A pintura mural nas catedrais galegas. Séculos XVI-XVIII. Santiago de Compostela: Tórculo.

- Fernández Fernández, P. (2017). El escultor Juan de Castro, contemporáneo y émulo de Francisco de Moure en la zona suroccidental de Asturias durante el primer tercio del siglo XVII. Quintana, 16, 239-262. https://doi.org/10.15304/qui.16.3865

- Fernández Fernández, P. (2018). Guía artística de Cangas del Narcea. Iglesias, monasterios y capillas. Cangas del Narcea: Tous pa Tous. Sociedad Canguesa de Amantes del País, Ayuntamiento de Cangas del Narcea.

- Fernández Gasalla, L. (2008). La biblioteca del arquitecto Diego Ibáñez Pacheco y la recepción e interpretación de la tratadística italiana en la Galicia Oriental (1623-1694). En XV Congreso Nacional de Historia del Arte (CEHA). Modelos, intercambios y recepción artística (de las rutas marítimas a la navegación en red). Vol. I. Palma de Mallorca: Universitat de les Illes Balears, 323-335.

- Franco Mata, A. (1998). Escultura gótica inglesa de Mondoñedo en el marco europeo. Compostellanum, 43, 927-952.

- García Iglesias, J.M. (1989). Pinturas murais de Galicia. Santiago de Compostela: Xunta de Galicia.

- Gómez Darriba, J. (2018). El maestro trasmerano Pedro de Morlote y la nueva cabecera de la catedral de Mondoñedo (1598-1603). Quintana, 17, 239-259. https://doi.org/10.15304/ qui.17.5173

- Gómez Darriba, J. (2020). La ciudad de Mondoñedo en los siglos XVII y XVIII. Construcción y nueva imagen de un centro de poder episcopal. Santiago de Compostela: Universidade de Santiago de Compostela (tesis doctoral).

- González Reboredo, J.M. et al. (1980). Inventario artístico de Lugo y su provincia. Vol. IV. Madrid: Ministerio de Cultura.

- Goy Diz, A. (1996). La actividad de un maestro cántabro en tierras de Lugo: Diego Ibáñez 
Pacheco. Altamira, 52, 223-261.

- Goy Diz, A. (2007). A actividade artística en Santiago, 1600-1648. Vol. II. Santiago de Compostela: Consello da Cultura Galega.

- Lence-Santar y Guitián, E. (1910a). Mondoñedo: El Convento de Alcántara. Mondoñedo: César G. Seco Romero.

- Lence-Santar y Guitián, E. (1910b). El Convento de Villanueva de Lorenzana y el de S. Francisco de Vivero. Mondoñedo: César G. Seco Romero.

- Lence-Santar y Guitián, E. (1911). Del Obispado de Mondoñedo. Mondoñedo: s. e.

- Lence-Santar y Guitián, E. (1950). La pesca de ballenas en la costa de la antigua provincia de Mondoñedo. Boletín de la Comisión provincial de Monumentos Históricos y Artísticos de Lugo, 2 (34), 100-104.

- Lence-Santar y Guitián, E. (1951). Nuestra Señora la Grande o la Inglesa de la Catedral de Mondoñedo. Cuadernos de Estudios Gallegos, 6 (18), 65-82.

- Monterroso Montero, J.M. (1998). El retrato como imagen de una sociedad. En Ve VI Semanas Galegas de Historia. Morte e sociedade no noroeste peninsular. Un percorrido pola Galicia cotiá. Santiago de Compostela: Asociación Galega de Historiadores, 397-416.

- Pérez Costanti, P. (1930). Diccionario de artistas que florecieron en Galicia durante los siglos XVI y XVII. Santiago: Seminario C. Central.

- Ramallo Asensio, G. (1985). Escultura Barroca en Asturias. Oviedo: Instituto de Estudios Asturianos.

- Rúa Veloso, O. (2005). Heráldica del Municipio de Mondoñedo. Lugo: Diputación Provincial de Lugo.

- Sánchez Ameijeiras, R. (1999). Devociones e imágenes medievales en la provincia eclesiástica de Mondoñedo. Estudios Mindonienses, 15, 375-409. 